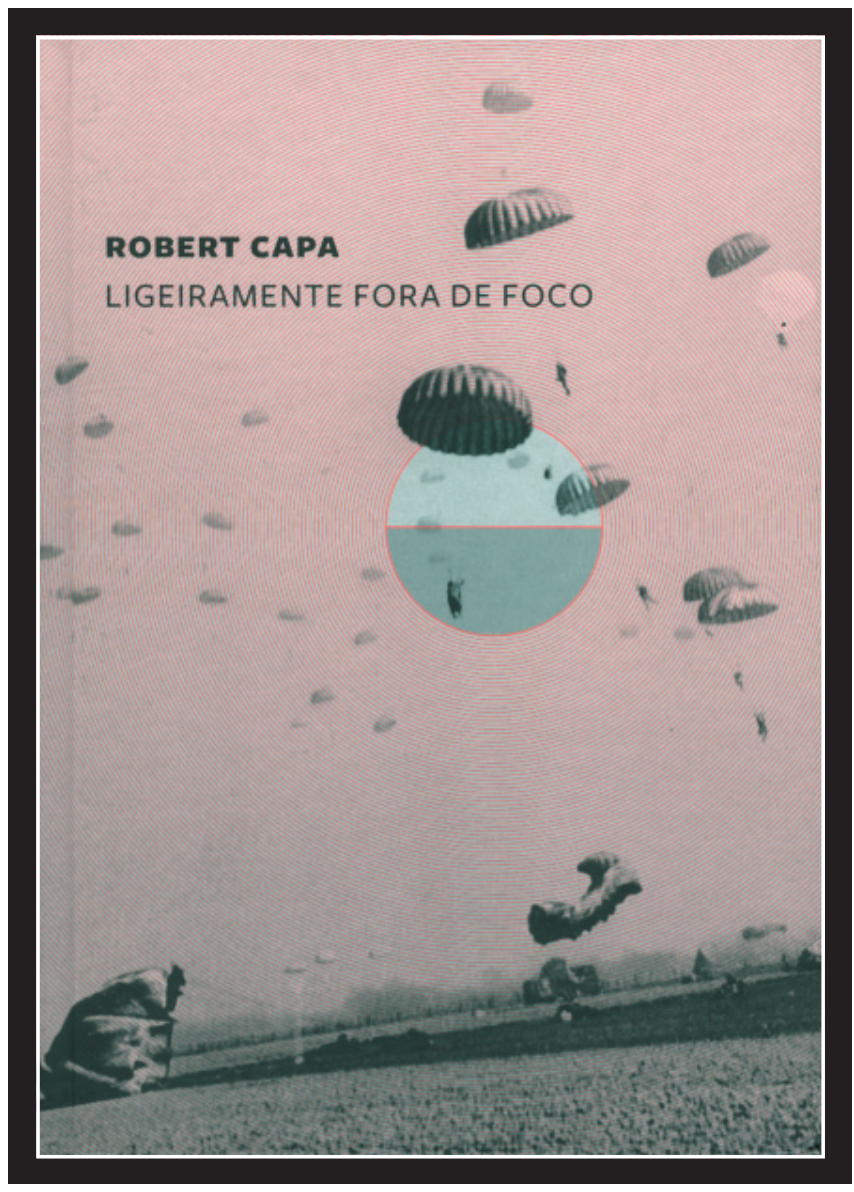

Ligeiramente fora de foco, de Robert Capa. Prefácio de Cornell Capa. Introdução de Richard Whelan. São Paulo: Cosac Naify, 2010, 296 p. 


\title{
A Segunda Guerra Mundial pelas lentes de Robert Capa
}

\author{
II World War by Robert Capa's lens
}

\author{
Ana Carolina Felipe Contato *
}

"Se suas fotos ainda não estão boas o suficiente, é porque você ainda não está perto o suficiente." A frase que se tornaria a marca registrada de um dos mais importantes fotógrafos de guerra seria também - e ironicamente - a tradução de seu fim. Robert Capa, expoente da fotografia de guerra no século XX teve seus cliques interrompidos ao pisar em uma mina terrestre quando documentava a guerra da Indochina francesa, em 1954. Antes disso, porém, registrou por meio de suas lentes a fragilidade humana e as desgraças provocadas por cinco guerras, a primeira delas a Guerra Civil Espanhola, entre 1936 e 1939, que rendeu a imagem mais polêmica de sua carreira (Figura 1).

Figura 1 - Morte de um soldado republicano

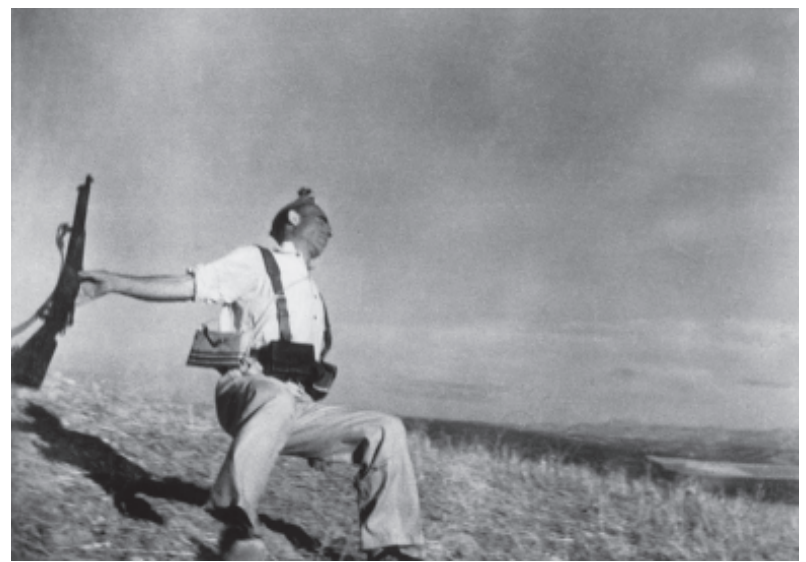

* Graduada em Comunicação Social - Habilitação Jornalismo pela Universidade Estadual de Londrina. Mestranda em Comunicação pela mesma instituição. Bolsista da Capes. E-mail: anaccontato@gmail.com 
A cobertura que o tornou célebre, no entanto, foi a da Segunda Guerra Mundial, cujas histórias - um tanto ficcionais, mas em sua maioria relatos fiéis - resultaram no livro Ligeiramente for a de foco de sua própria autoria. A narrativa da invasão dos territórios ocupados por Hitler é permeada por seu envolvimento amoroso com a jovem Elaine, que graças aos seus cabelos mescla de ruivo com louro, ganhou de Capa o apelido de Pinky.

O livro começa com o relato do fotógrafo, invariavelmente passando por dificuldades financeiras. Húngaro, com passagens profissionais por diversos países, entre os quais Alemanha, França e Estados Unidos, foi chamado pela revista Collier's para ir à Europa a fim de cobrir a guerra. Tratado como estrangeiro perigoso e com um inglês sofrível - que o acompanharia por toda vida - Robert Capa consegue permissão para ir à Inglaterra. Na viagem, fez amizade com o comodoro do navio, que o confundiu com o cineasta Frank Capra, obrigando-o a contar ao longo do trajeto marítimo histórias sobre uma Hollywood que ele jamais havia conhecido.

Esta, aliás, era uma das grandes habilidades de Capa: com boas doses de álcool e anedotas fantasiosas, conquistava desde as tropas aliadas até o alto escalão da embaixada britânica em Washington. Sua empatia o levou a ser admitido nas rodas de pôquer dos soldados e, mesmo sem saber jogar, aproveitou para iniciar seus registros da segunda grande guerra, ainda que fossem nas mesas de bar na Inglaterra.

No interior britânico, pouco antes de partir para sua primeira missão no norte da África, conheceu sua garota rosada, como costumava chamála. Embora desconhecesse seu nome completo ou endereço, partiu para o front pensando em voltar à Europa para reencontrá-la.

Logo na primeira noite em solo africano, Capa fora alojado numa escola árabe, com seu saco de dormir junto à parede; pouco depois, acordou com o rosto queimando - tinha sido atacado por percevejos. Esse seria apenas o começo. Após seis meses de bombardeios e ataques aéreos muito fastidiosos, decidiu voltar à Europa e encontrar Pinky. Descobriu que a Collier's o havia demitido e precisava urgentemente de 
um novo emprego. Foi à filial da revista Life, em Londres, e soube por sua amiga Crocky, a encarregada do escritório, que:

Grandes coisas iam ocorrer em breve ao longo do Mediterrâneo, e achava que se eu conseguisse voltar para o norte da África antes que o exército ficasse sabendo que eu havia sido despedido e se conseguisse, de alguma forma, fazer alguma coisa depressa e dar um furo nos outros fotógrafos, então a situação podia mudar de figura. (CAPA, 2010, p.94).

Assim, no dia seguinte ao seu retorno, Robert Capa voltava para o norte da África, para a guerra e para longe de Pinky. Já nos campos de batalha, foi o primeiro fotógrafo a registrar a invasão norte-americana na Sicília e teve também sua estreia como paraquedista, saltando sobre território italiano. Pousou, na verdade, sobre uma árvore e ficou preso a noite toda, até que soltados viessem resgatá-lo.

Na Itália, foram recebidos como heróis, com calorosos apertos de mão, saudações e comida abundante - nada que contribuísse para as fotografias sangrentas que esperava tirar. Ainda desempregado e procurado pelo Departamento de Relações Públicas para voltar à Europa, decidiu seguir sozinho - e a pé - em busca de cenários mais apropriados para suas lentes. Pouco depois, descobriu que a revista Life o havia admitido e que, concomitantemente, havia pego malária. Recuperado, participou da tomada de Nápoles e fotografou o funeral de vinte crianças que, durante quatorze dias, lutaram contra os alemães com armas em punho (Figura 2). "Eu me arrastei de montanha em montanha, de trincheira em trincheira, tirando foto de lama, miséria e morte." (CAPA, 2010, p.155).

Os horrores da guerra começaram a minar seu desejo por registrála e Capa decidiu dar um descanso a si e às suas câmeras, passando um período em Londres, ao lado da namorada. Após adiar uma cirurgia por quatro semanas, o apêndice de Pinky havia estourado e a temporada inglesa dos dois não fora das mais românticas.

Enquanto a moça estava internada, ele descobriu um bar com generoso estoque de bebidas e passou a frequentá-lo; numa dessas noites, 
reencontrou seu velho amigo Ernest Hemingway. O escritor ganhou então uma bela festa no apartamento de Capa e Pinky. Na volta para casa, Hemingway e o médico que lhe dava carona bateram o carro e o escritor levou 48 pontos na cabeça.

Figura 2 - Funeral de crianças em Nápoles

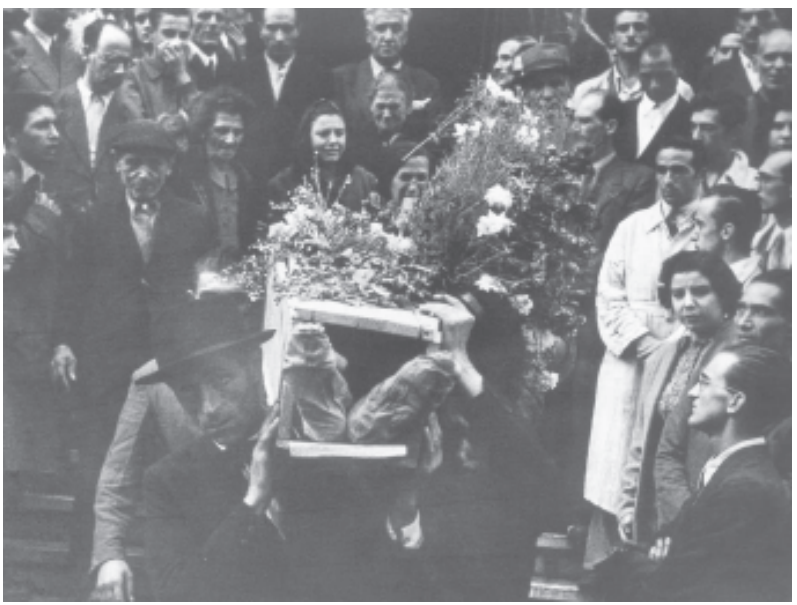

Sendo o único sadio em Londres, decidiu partir novamente para a guerra, esperando pelo “Dia D”, que se aproximava. O capítulo dedicado à invasão da praia de Omaha, na costa da Normandia, narra com riqueza de detalhes desde o momento do planejamento das tropas, ainda nos navios, até o desembarque no mar gelado, em que Capa se somou aos soldados e fez registros únicos do começo da derrocada nazista. Mesmo chegando à areia, decidiu voltar para a embarcação e ajudar a transportar macas com feridos, ao invés de disparar sua câmera. Poderia ter voltado ao front, mas acordou horas mais tarde e leu em seu pescoço a inscrição "caso de exaustão" (Figura 3).

Embora arrependido por não haver permanecido na praia durante toda a invasão, Robert Capa fora tratado como herói - o outro fotógrafo destacado para a missão não tivera coragem nem de sair do barco. Das 106 fotografias tomadas, apenas oito se salvaram, em razão do excesso de calor a que os filmes foram expostos durante o processo de revelação. 
Ainda assim, foram as oito poses mais reproduzidas desde então quando se trata de Segunda Guerra Mundial.

Figura 3 - Capa em "caso de exaustão"

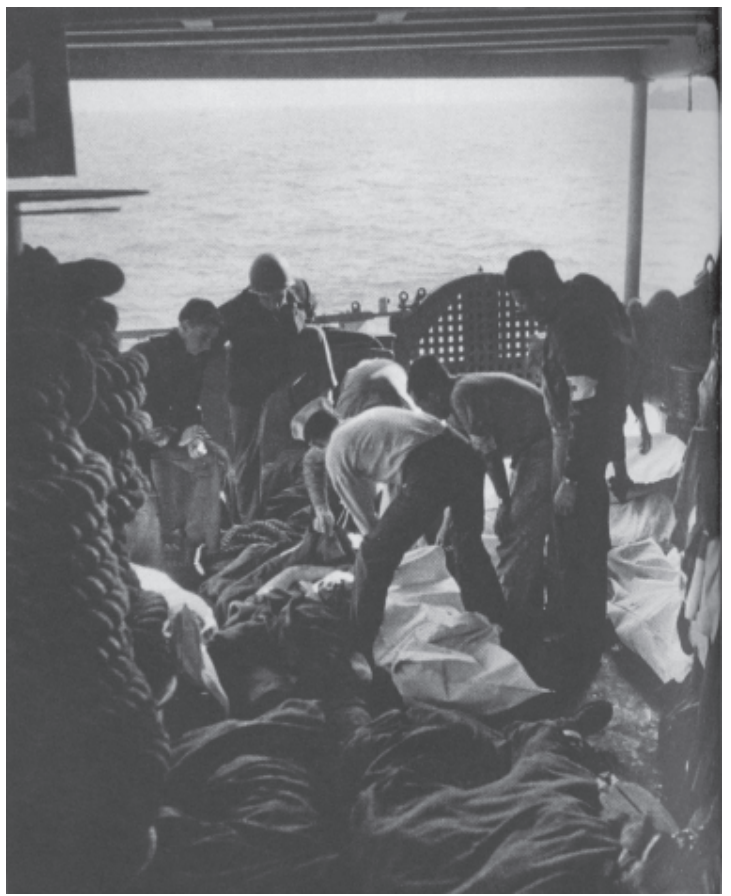

Com a praia definitivamente ocupada, o fotógrafo decidiu voltar e acompanhar as tropas até Paris, o marco da vitória dos Aliados. Ao longo da caminhada, chegou a se juntar ao pequeno pelotão organizado por Hemingway, mas um desentendimento entre os dois fez com que ele voltasse a acompanhar o $3^{\circ}$ Exército.

A estrada para Paris estava aberta e todos os parisienses saíram à rua para tocar o primeiro tanque, beijar o primeiro homem, cantar e chorar. Nunca houve tanta gente tão contente tão cedo [...] os milhares de rostos no visor de minha câmera foram ficando mais e mais borrados; aquele visor estava muito, muito molhado. Passamos pelo quartier onde eu havia morado seis anos, passamos por minha casa junto ao Lion de Belfort. Minha 
concièrge estava acenando com um lenço e eu gritava para ela de cima do tanque em movimento: 'C'est moi, c'est moi.' (CAPA, 2010, p.237-238).

Embora contente com a libertação de Paris, havia muito que ele e Pinky não se encontravam, e a indefinição daquele relacionamento já tinha consumido em boa parte a paciência da moça. Capa prometeu a ela que os dois poderiam se encontrar em Paris, disfarçando-a de repórter. Porém, a Life ordenou que ele voltasse para a guerra. Pinky não conseguiu ir a seu encontro e Chris Scott, major das tropas aliadas e amigo de Capa estava se apaixonando por ela - e ela por ele.

Já na Alemanha, ele fez seu segundo salto de paraquedas e ótimas fotografias dos soldados ainda no ar e depois de pousarem, já em solo inimigo. A grande guerra chegava ao fim, assim como seu relacionamento. Pouco depois da queda do nazismo, Capa recebeu a notícia que Chris Scott estava prestes a se casar a com uma "certa moça" inglesa.

Para além do romance belamente entrelaçado aos desdobramentos da Segunda Guerra Mundial, Robert Capa demonstra em Ligeiramente fora de foco sua veia literária, que somada às fotografias de flagrantes, $\mathrm{o}$ tornaram referência na arte de escrever - com luz e palavras. 